\title{
IMPROVING SILICA-BASED SPIN-COLUMN EFFICIENCY FOR RNA ISOLATION FROM FFPE TISSUE
}

\author{
Pantelis Dimaras, Oskan Tasinov, Desislava Ivanova, Yoana Kiselova-Kaneva, \\ Diana Ivanova
}

\author{
Department of Biochemistry, Molecular Medicine and Nutrigenomics, \\ Faculty of Pharmacy, Medical University of Varna
}

\begin{abstract}
RNA isolation from formalin-fixed paraffin embedded tissue has been a target for improvement for many years. The major limitation is the highly degraded RNA, which in turn increases the demand of the highest yields possible during isolation procedures. In this study, we compared the purification efficacy of RNA between the traditional ethanol precipitation and a modified protocol, which includes the use of silica-based spin-columns for RNA purification and recovery. We also modified and assessed the efficacy of a protocol for effective decontamination and regeneration of spin-columns.
\end{abstract}

Keywords: RNA extraction, RNA purification, ethanol precipitation, silica-based spin-columns

\section{INTRODUCTION}

For many decades formalin fixation of tissue followed by embedding in paraffin (FFPE) has been the method of choice to preserve tissue morphology, thus allowing histological study of biopsy specimen for assisting in the establishment of clinical diagnosis (1). With the development of molecular biology analytical methods, a need to isolate genetic material for molecular diagnostics has emerged (2). Many studies on characterization and quantification of RNA molecules have been performed mainly by utilizing dif-

Address for correspondence:

Pantelis Dimaras

Department of Biochemistry, Molecular Medicine and

Nutrigenomics

Faculty of Pharmacy

Medical University of Varna

84 Tzar Osvoboditel Blvd, Varna

e-mail:pantedimaras@yahoo.gr

Received: April 5, 2017

Accepted: June 5, 2017 ferent kits for RNA extraction (3-5). Although DNA appears to be quite stable, the major disadvantage of the FFPE tissue preservation is the highly degraded RNA molecules obtained during isolation procedures (6). After extraction of RNA with the assistance of a proteinase $\mathrm{K}$ lysis buffer or phenol-based reagents, quite an effective way to overcome this obstacle is by including silica-based spin columns during the isolation procedure (7). Silica-based spin columns are proved to recover high yields of extracted nucleic acid even from tough-to-lyse tissues compared to ethanol precipitation (8). In order to be reused, silica-based spin-columns can be decontaminated by alkaline treatment with the addition of nonionic detergent Triton X-100 and regenerated by acidic treatment $(\mathrm{pH}=4)$ by utilizing a sodium acetate/ acetic acid buffer (9).

The aim of this study was to compare and prove the superiority of silica-based spin column RNA purification, as well as the efficacy of decontamination and regeneration of used columns with concomitant 
use of lab-made RNA wash buffers for use with the columns. In this study, we have validated a modified protocol for the effective decontamination and regeneration of used columns and the efficiency of additional RNA purification performed with used columns.

\section{MATERIALS AND METHODS}

\section{RNA extraction}

Six FFPE tissue blocks were taken to retrieve tissue. Five tissue sections of $10 \mu \mathrm{m}$ thickness were obtained from each FFPE tissue block and were placed in $1.5 \mathrm{~mL}$ microcentrifuge tubes. The procedure was repeated once more until a final number of 12 sample tubes were obtained. Tissue samples were deparaffinized by adding $1 \mathrm{~mL}$ xylene to each, followed by a brief vortex and spin at $13.000 \mathrm{rpm}$ for $2 \mathrm{~min}$ at room temperature. Xylene was then removed by pipetting. The pelleted tissue was then washed from residual xylene by adding $1 \mathrm{ml}$ of absolute ethanol. Samples were briefly mixed by vortex followed by spin for $2 \mathrm{~min}$ at room temperature. Deparaffinized tissue was left to air dry with open tubes. Then, $100 \mu \mathrm{L}$ of Quickextract FFPE RNA extraction Lysis buffer (Epicentre, Illumina, USA) were added to the tissue sample. Samples were incubated at $56^{\circ} \mathrm{C}$ for $30 \mathrm{~min}$ and further heated to $80^{\circ} \mathrm{C}$ for $10 \mathrm{~min}$. Then, $1 \mathrm{~mL}$ of Accuzol (Bioneer, Republic of Korea) solution was added. Samples were mixed by vortex and incubated at room temperature for $8 \mathrm{~min}$. Then $200 \mu \mathrm{L}$ of chloroform were added. Samples were mixed by vortex and allowed to sit for $2 \mathrm{~min}$ and centrifuged for phase separation at $10.000 \mathrm{rpm}$ at $4^{\circ} \mathrm{C}$ for $15 \mathrm{~min}$. The aqueous phase was transferred to a new clear $1.5 \mathrm{~mL}$ microcentrifuge tube.

\section{RNA purification and recovery Ethanol precipitation}

Six samples were purified with the use of ethanol precipitation. An equal volume of isopropanol was added to the aqueous phase and mixed by vortex. The samples were incubated at $-20^{\circ} \mathrm{C}$ for 1 hour. Then, samples were centrifuged at $10.000 \mathrm{rpm}$ for $15 \mathrm{~min}$ at $4^{\circ} \mathrm{C}$. The nucleic acids formed a pellet at the bottom. The supernatant was discarded taking care not to dislodge the pellet and $1 \mathrm{~mL}$ of $75 \%$ ethanol was added to each sample and mixed by vortex. Sam- ples were centrifuged at $10.000 \mathrm{rpm}$ for $10 \mathrm{~min}$ at $4^{\circ} \mathrm{C}$. The supernatant was discarded and samples were left to dry. Finally, the pelleted RNA was resuspended in $15 \mu \mathrm{L}$ RNAse/DNAse free water.

\section{Silica-based spin-columns}

The RNA from the same tissue samples was purified with the use of silica-based spin-columns. An equal volume of ethanol was added to the aqueous phase and mixed by vortex. The samples were transferred to mini silica-based spin-columns (Zymoresearch, USA) and centrifuged at $10.000 \mathrm{rpm}$ for $1 \mathrm{~min}$. The flow-through was discarded. For the purification of RNA two buffers were created. The first buffer (A) was composed of $99 \%$ absolute ethanol and $1 \% 3 \mathrm{M}$ sodium acetate $\mathrm{pH}=6.7$. The second (B) was composed of $80 \%$ absolute ethanol, 19\% HPLC grade $\mathrm{H}_{2} \mathrm{O}$, and $1 \%$ TAE buffer $\mathrm{pH}=8.0$ (Applichem, Germany). Initially $400 \mu \mathrm{L}$ of buffer A was added to the column and centrifuged at $10.000 \mathrm{rpm}$ for $1 \mathrm{~min}$. The flow-through was discarded. Then, $400 \mu \mathrm{L}$ of buffer $\mathrm{B}$ was added to the column and centrifuged at 10.000 $\mathrm{rpm}$ for $1 \mathrm{~min}$. The flow-through was discarded. The same procedure was repeated with $700 \mu \mathrm{L}$ of buffer B. Columns were transferred to new clear $1.5 \mathrm{ml}$ microcentrifuge tube and loaded with $15 \mu \mathrm{L}$ of molecular biology grade $\mathrm{H}_{2} \mathrm{O}$. Columns were left to rehydrate for $5 \mathrm{~min}$ and then centrifuged at 13.000 rpm for 2 min to recover the RNA.

\section{Column decontamination and regeneration}

Two solutions were needed, one for purification and decontamination and one for purification. The first solution (A) consists of $0.2 \mathrm{M} \mathrm{NaOH}$ and $0.1 \%$ $\mathrm{v} / \mathrm{v}$ Triton X-100 and the second (B) consists of $50 \mathrm{mM}$ sodium acetate/acetic acid $\mathrm{pH}=4.0$ (9). First, $500 \mu \mathrm{L}$ of pre-warmed $\left(75^{\circ} \mathrm{C}\right)$ solution (A) was transferred to the column and gently pipetted paying attention to avoid agitation of the silica membrane with the pipet tip. Then the solution was removed by aspiration with the pipette in order to remove dissolved high molecular weight proteins or crude tissue particles, which cannot pass through the membrane. Additional $500 \mu \mathrm{L}$ of pre-warmed $\left(75^{\circ} \mathrm{C}\right)$ solution (A) was transferred to the column and was left for $10 \mathrm{~min}$. Columns were then centrifuged at $10.000 \mathrm{rpm}$ for 1 min and the flow-through was discarded. This procedure was repeated once more. Then $500 \mu \mathrm{L}$ of solution (B) were transferred to the columns and incu- 
Pantelis Dimaras, Oskan Tasinov, Desislava Ivanova et al.

bated for $5 \mathrm{~min}$. This step was followed by centrifugation at $10.000 \mathrm{rpm}$ for $1 \mathrm{~min}$ and the flow-through was discarded. Lastly, $700 \mu \mathrm{L}$ of HPLC grade water were transferred to the columns followed by centrifugation at $10.000 \mathrm{rpm}$ for $1 \mathrm{~min}$ and the flow-through was discarded. Columns were stored at $4^{\circ} \mathrm{C}$. Three decontaminated and regenerated silica-based spin columns were placed in a sterile $1.5 \mathrm{~mL}$ microcentrifuge tube and then $15 \mu \mathrm{L}$ of HPLC grade water was transferred to the columns. The columns were centrifuged at $13000 \mathrm{rpm}$ for $1 \mathrm{~min}$. The collected flowthrough was measured through spectrophotometry.

Six RNA samples were in turn purified with the use of decontaminated and regenerated columns and additionally with the use of new silica-based spin columns. For both groups the purification process was performed with lab-made RNA wash buffers, and the procedure followed as previously mentioned. ware. For the estimation of statistical significance, students $t$-test were performed with $p<0.05$ considered as significant.

\section{RESULTS}

\section{RNA purification efficacy}

RNA yields were highly variable and dependent on initial tissue quantity, which underwent extraction. Six identical tissue samples were purified by ethanol precipitation and silica-based spin-columns. The purification efficacy was estimated from the yield and purity of extracted and purified RNAs (Table 1). The concentration of the purified RNA through ethanol precipitation ranged from $226.28 \mathrm{ng} / \mu \mathrm{L}$ to $495.14 \mathrm{ng} / \mu \mathrm{L}$, while the silica-based spin column purified samples ranged from $118.24 \mathrm{ng} / \mu \mathrm{L}$ to $2084.5 \mathrm{ng} /$ $\mu \mathrm{L}$. The purity of the samples measured by $\mathrm{A}_{260 / 280}$ resulted to an average of $1.752 \pm 0.089$ for the ethanol precipitation and an average of $1.94 \pm 0.095$ for the sil-

Table 1. RNA yield and purity obtained through ethanol precipitation and silica-based spin-column purification. ${ }^{*} p<0.05$ ethanol precipitation $v$ s. silica based spin-column

\begin{tabular}{l|c|c|c|c|}
\multicolumn{2}{|c|}{ Ethanol precipitation } & \multicolumn{2}{c|}{ Silica-based spin-column } \\
\hline Sample & $\begin{array}{c}\text { RNA Concentration } \\
{[\mathrm{ng} / \mu \mathrm{L}]}\end{array}$ & $\mathrm{A}_{260 / 280}$ & $\begin{array}{c}\text { RNA Concentration } \\
{[\mathrm{ng} / \mu \mathrm{L}]}\end{array}$ & $\mathrm{A}_{260 / 280}$ \\
1 & 495.14 & 1.776 & 2084.5 & 1.898 \\
2 & 399.3 & 1.762 & 177.12 & 1.922 \\
3 & 226.28 & 1.611 & 2012.4 & 1.99 \\
4 & 262.84 & 1.821 & 118.24 & 2.025 \\
5 & 243.8 & 1.855 & 2021.04 & 1.781 \\
6 & 585.24 & 1.689 & 929.28 & 2.029 \\
Mean RNA purity \pm SD & $1.752 \pm 0.089$ & - & $1.940 \pm 0.095$ \\
$p$ value of $\mathrm{A}_{260 / 280}$ & - & - & $0.037^{*}$ \\
\hline
\end{tabular}

\section{RNA quantification through spectrophotometry}

RNA sample yield and purity was calculated by spectrophotometry measuring absorptions at 260, 280 and 320nm using Take3 plate of Synergy 2 instrument (Biotek, USA). At $260 \mathrm{~nm}$ wavelength nucleic acids readily absorb the emitted light energy and at $280 \mathrm{~nm}$ the proteins. The $320 \mathrm{~nm}$ absorption value is measured as an internal blank.

\section{Statistical analysis}

All data presented have been processed using GraphPad Prism V6 and Microsoft Excel 2013 soft- ica-based spin column purification procedure.

\section{Decontamination efficacy}

The efficacy of decontamination of silica-based spin columns was estimated by measuring the absorption at 260 and $280 \mathrm{~nm}$ of the elution volume (Table 2). The values of first sample were $A_{260}=0.005$ and $\mathrm{A}_{260}=0.002$ and for the rest two samples $\mathrm{A}_{260}=-$ $0.001, \mathrm{~A}_{280}=-0.001$ and $\mathrm{A}_{260}=-0.002, \mathrm{~A}_{280}=-0.001$, respectively. The A values below 0.01 are considered extremely low for the first sample and for the remaining two, they were negative. 
Table 2. Silica-based spin-column decontamination efficacy

\begin{tabular}{lccc|c} 
Column & $\begin{array}{c}\text { RNA } \\
\text { concentration } \\
{[\mathrm{ng} / \mu \mathrm{L}]}\end{array}$ & $\mathrm{A}_{260}$ & $\mathrm{~A}_{280}$ & $\mathrm{~A}_{260 / 280}$ \\
\hline 1 & 3.82 & 0.005 & 0.002 & 2.076 \\
2 & -0.42 & -0.001 & -0.001 & 0.404 \\
3 & 1.34 & -0.002 & -0.001 & 2.393 \\
\hline
\end{tabular}

Comparison of RNA purification efficacy between new and decontaminated-regenerated silicabased spin columns.

Six RNA tissue samples were purified by new and decontaminated-regenerated silica-based spincolumns. The purification efficacy was estimated from the yield and purity of extracted and purified RNAs (Table 3). The concentration of the purified RNA with the use of new silica-based spin-columns ranged from $375.58 \mathrm{ng} / \mu \mathrm{L}$ to $909.58 \mathrm{ng} / \mu \mathrm{L}$, while the respective concentration of RNA obtained with decontaminated-regenerated silica-based spin columns ranged from $299.62 \mathrm{ng} / \mu \mathrm{L}$ to $828.16 \mathrm{ng} / \mu \mathrm{L}$. The purity of the samples measured by $\mathrm{A}_{260 / 280}$ resulted in an average of $2.031 \pm 0.039$ for the new silica-based spincolumns and an average of $2.004 \pm 0.048$ for the decontaminated-regenerated silica-based spin column purification procedure.

Table 3. RNA yield and purity obtained through new silica-based spin-column and decontaminated-regenerated column purification

\begin{tabular}{l|c|c|c|c|} 
& \multicolumn{2}{|c}{ New Silica-based spin-column } & \multicolumn{2}{c|}{ Decontaminated-regenerated Silica-based spin-column } \\
\hline Sample & $\begin{array}{c}\text { RNA Concentration } \\
{[\mathrm{ng} / \mu \mathrm{L}]}\end{array}$ & $\mathrm{A}_{260 / 280}$ & $\begin{array}{c}\text { RNA Concentration } \\
{[\mathrm{ng} / \mu \mathrm{L}]}\end{array}$ & $\mathrm{A}_{260 / 280}$ \\
1 & 835.18 & 2.049 & 436.5 & 1.982 \\
2 & 375.58 & 1.996 & 299.62 & 1.944 \\
3 & 436.38 & 1.969 & 440.48 & 2.009 \\
4 & 821.74 & 2.067 & 740.88 & 2.073 \\
5 & 909.58 & 2.044 & 828.16 & 2.042 \\
6 & 771.74 & 2.059 & 355.6 & 1.973 \\
\multicolumn{2}{l}{ Mean RNA purity $\pm \mathrm{SD}$} & $2.031 \pm 0.039$ & - & $2.004 \pm 0.048$ \\
\multicolumn{2}{l}{$p$ value A $260 / 280$} & - & - & $0.235 \mathrm{~N} / \mathrm{S}$ \\
\hline
\end{tabular}

\section{DISCUSSION}

Silica-based spin-columns combined with labmade buffers provide higher yields in regard to RNA concentration. RNA purified by silica-based spincolumns showed higher purity according to the average of absorption ratio $\mathrm{A}_{260 / 280}$ of $1.94 \pm 0.095 \mathrm{com}$ pared to the average of absorption ratio $\mathrm{A}_{260 / 280}$ of $1.752 \pm 0.089$ of the purified RNA samples with ethanol precipitation. Values above 1.8 show an RNA sample with high purity, relatively free from contaminants. The general superiority of silica-based spin-columns against ethanol precipitation can be observed through the higher absorption values at $260 \mathrm{~nm}$ (Table 1), which gives the concentration value. Additionally, the average absorption ratio $\mathrm{A}_{260 / 280}$ for the purified RNA with the use of silica-based spin columns was significantly higher $(p=0.037)$ than the ethanol precipitation (Table 1). Moreover, the high amounts of RNA recovered show the effective binding of RNA molecules to the silica membrane thus preventing the loss of RNA during washing cycles.

Furthermore, the modified protocol for regenerating columns provides efficient decontamination. The $\mathrm{A}_{260}$ and $\mathrm{A}_{280}$ values show that the columns were free from nucleic acids and other contaminants, namely proteins, and thus allow them to be reused for purification of further RNA samples (Table 2).

By comparing the new silica-based spin columns with the decontaminated-regenerated columns, we conclude that the purification efficacy is

highly similar as estimated by the absorption ratio $\mathrm{A}_{260 / 280}$, since the purity shows no statistically significant difference between the two variables (Table 3). We did not use RNA concentration to conclude 
Pantelis Dimaras, Oskan Tasinov, Desislava Ivanova et al.

about the efficacy of any method since FFPE tissue samples from the same block vary in tissue quantity. Thus, it may lead to false conclusions.

Decontaminated and regenerated silica-based spin columns prove to be equally effective in RNA purification as compared to new ones. However, we recommend that RNA samples obtained from reused columns should be used only for quantitative analyses and not for qualitative detection, as the risk of cross contamination still exists.

\section{CONCLUSION}

Silica-based spin-columns provide maximum yield and purity of the isolated RNA. Lab-made buffers provide efficacious purification of the RNA during washing cycles. Decontamination of spin columns with non-ionic detergent containing alkaline buffer and regeneration with acidic sodium acetate buffer allows them to be reused for subsequent extractions of RNA, as effectively as the new ones. In conclusion, we improved the efficiency of silicabased spin-columns in order to provide an effective and inexpensive way to perform RNA extractions from limited tissue samples, like FFPE.

\section{Acknowledgements}

The Medical University of Varna supported this study through "Science" project No 16020.

\section{REFERENCES}

1. Chung J-Y, Braunschweig T, Williams R, Guerrero N, Hoffmann KM, Kwon M, et al. Factors in tissue handling and processing that impact RNA obtained from formalin-fixed, paraffin-embedded tissue. J Histochem Cytochem [Internet]. 2008;56(11):1033-42. Available from: http://www. pubmedcentral.nih.gov/articlerender.fcgi?artid=256 9903\&tool=pmcentrez\&rendertype $=$ abstract

2. Gilbert MTP, Haselkorn T, Bunce M, Sanchez JJ, Lucas SB, Jewell LD, et al. The Isolation of Nucleic Acids from Fixed, Paraffin-Embedded TissuesWhich Methods Are Useful When? PLoS One. 2007;2(6). doi: 10.1371/journal.pone.0000537

3. Doleshal M, Magotra AA, Choudhury B, Cannon BD, Labourier E, Szafranska AE. Evaluation and validation of total RNA extraction methods for microRNA expression analyses in formalin-fixed, paraffin-embedded tissues. J Mol Diagn [Internet]. 2008;10(3):203-11. Available from: http://www.sciencedirect.com/sci-
ence/article/pii/S1525157810601511. doi: 10.2353/ jmoldx.2008.070153

4. Bohmann K, Hennig G, Rogel U, Poremba C, Mueller BM, Fritz P, et al. RNA extraction from archival formalin-fixed paraffin-embedded tissue: A comparison of manual, semiautomated, and fully automated purification methods. Clin Chem. 2009;55(9):1719-27. doi: 10.1373/ clinchem.2008.122572

5. Li J, Smyth P, Flavin R, Cahill S, Denning K, Aherne $\mathrm{S}$, et al. Comparison of miRNA expression patterns using total RNA extracted from matched samples of formalin-fixed paraffin-embedded (FFPE) cells and snap frozen cells. BMC Biotechnol. 2007;7:36. doi: 10.1186/1472-6750-7-36

6. von Ahlfen S, Missel A, Bendrat K, Schlumpberger M. Determinants of RNA quality from FFPE samples. PLoS One. 2007;2(12). doi: 10.1371/journal. pone. 0001261

7. Tan SC, Yiap BC, Tan SC, Yiap BC. DNA, RNA, and protein extraction: the past and the present. J Biomed Biotechnol [Internet]. 2009;2009:574398. Available from: http://www.ncbi.nlm.nih.gov/ pubmed/20011662\%5Cnhttp://www.pubmedcentral.nih.gov/articlerender.fcgi?artid=PMC2789530. doi: $10.1155 / 2009 / 574398$

8. Lee HY, Park MJ, Kim NY, Sim JE, Yang WI, Shin KJ. Simple and highly effective DNA extraction methods from old skeletal remains using silica columns. Forensic Sci Int Genet. 2010;4(5):275-80. doi: 10.1016/j.fsigen.2009.10.014

9. Nicosia A, Tagliavia M, Costa S. Regeneration of total RNA purification silica-based columns. Biomed Chromatogr. 2010;24(12):1263-4. 